\title{
ESTIMATION OF CROP COEFFICIENT FOR ONION PLANT UNDER DELTA NILE CONDITIONS
}

Hend M. Nassar, El-Shinawy M.Z., El-Behairy U.A. and Abou-Hadid A.F. Horticulture Dept., Fac. of Agric., Ain Shams Univ., P.O. Box 68, Hadayek Shoubra 11241, Cairo, Egypt

*Corresponding author: hend667@agr.asu.edu.eg

Received 13 November, 2019

Accepted 2 December, 2019

\section{ABSTRACT}

Egypt is a semi-arid region and consequently agriculture in Egypt depends on specific sources of water; the extremely important of which is the River Nile. So, the rationalization of water of irrigation is essential and the evaluation of water requirements is necessary for each crop. Therefore, the objectives of this study were to estimate crop coefficient (Kc) for different growth stages of onion (Allium cepa L.). The study was carried out at the Experimental Farm of the Institute of Post-Graduate Studies and Research in Arid Lands, Ain Shams University at Shubra El Kheima, Qalyubia Governorate, Egypt. The experiment was conducted in 2014/2015 and 2015/2016 seasons under conditions of volumetric lysimeter (dimensions $1 \times 1 \times$ $1 \mathrm{~m}$ ) and filled with three types of soil (clay, sandy clay and sand) with three levels of water requirement $(75,100$, and $125 \%$ of ETc) for the crop. Onion cv. Giza 61 was used. The results indicated that the increases of irrigation water levels (100 and $125 \%$ ETc) were the best treatments for some growth parameters. The averages of crop coefficient values were $0.47,0.5,1.24$ and 0.99 during establishment, development, mid-season and endseason growth stages, respectively. Water use efficiency (WUE) for onion was determined for all treatments and the effects showed that the application of $100 \%$ ETc gave the highest values.

Keywords: Onion, Alium cepa L., Water requirement, Evapotranspiration, Crop coefficient, Drainage lysimeters, Penman-Monteith

\section{INTRODUCTION}

Water is supposed to be one of the most important limiting elements in the development of agriculture, specifically in the arid and semi-arid zones of the world. Agricultural irrigation makes use about $70 \%$ of water extract worldwide. Moreover, today up to ninety five percentage of available water is used for irrigation in several developing countries inclusive of Egypt. Egypt is a semiarid area and the major source of agricultural irrigation is the River Nile which supplies Egypt with an annual ration of 55 billion cubic meters. For the scarcity of water sources in Egypt, water needs to be divided efficiently for the crops at the right time with an effective quantity. Thus, it is highly essential to optimize WUE through acceptably irrigation scheduling. The estimating of water requirements is dependent on calculating the crop coefficient $(E T c=$ $\mathrm{ETo} \times \mathrm{Kc}$ ). The $\mathrm{Kc}$ is registered as the proportion of reference and crop ET. The ETo is a normally utilized idea in water system planning and demonstrates to the evapotranspiration from a wellwatered grass. Potential evapotranspiration can be computed using oftentimes available weather parameters and determined by using the FAO Penman-Monteith technique (Allen et al 1998). There are direct and indirect methods to estimate crop water requirements; direct strategies such as using lysimeters and indirect strategies such as utilizing some water system applications as crop wat 8.0 after estimating actual evapotranspiration and reference evapotranspiration (Surendran et al 2015). A lysimeter is basically a holder which isolates soil and water hydrologically from its environment, yet at the same time represents the bordering soil as closely as possible. So, it is serious to define the 
water requirements of the crop. All plants do never again utilize a similar amount of water under the equivalent climatic conditions. So, irrigation scientists have developed crop coefficients that confer a relationship between ETo and the amount of water (ETc) that the crop of interest uses. For the sake of avoid the underestimation or overestimation of crop water consumption, know-how of the exact water loss through actual evapotranspiration is necessary for sustainable improvement and environmentally water management.

The $\mathrm{Kc}$ for a crop might also vary from one place to another depending on climate, soil, crop variety, crop type, irrigation methods, etc. (Kang et al 2003). Crop coefficient was estimated for most of crops in Egypt except some crops such as onion which is considered as an important vegetable crop in Egypt.

Onion (Allium cepa L.) is one of the main vegetable crops grown in arid and semiarid regions across the world. Onions are a yield of global significance with focuses of generation extending from the warm tropics and calm zones to high latitudes in the northern hemisphere (Brewster, 2008). The global production of onion was 97.8 million $\mathrm{Mg}$ from 5.2 million ha, with a production in Egypt 2.3 million $\mathrm{Mg}$ from 68.053 ha (FAO, 2017). Until now, crop coefficient for onion is not determined under Egyptian weather conditions, so the aim of this study was to determine the water requirements and crop coefficient for different development stages of onion (Allium cepa L.) in Egypt utilizing lysimeter technique.

\section{MATERIALS AND METHODS}

The present study was carried out at the Experimental Farm of the Institute of Post-Graduate Studies and Research in Arid Lands, Ain Shams University at Shubra El kheima, Qalyubia Governorate, Egypt. The experiment was conducted in 2014/2015 and 2015/2016 seasons under volumetric lysimeter conditions to estimate the crop coefficient $(\mathrm{Kc})$ and compute irrigation scheduling for different growth stages of onion (Allium cepa L.) in Egypt.

\section{Experimental design}

The experiment was spread out in a totally randomized design with three replications. The experiment included three levels of water requirements $(75,100$, and $125 \%$ of ETc) for the crop and three types of soils (clay, sand and sandy clay). Thus, the experiment consisted of 27 plots ( 27 concrete lysimeter units). Each unit was $1 \times 1 \times 1 \mathrm{~m}=1 \mathrm{~m}^{3}$. The chemical properties of the $0-30 \mathrm{~cm}$ soil layer in the experimental soils are shown in Table (1).

To measure the ETc, drainage lysimeters were used in this study. Each unit of lysimeters consisted of three levels of drainage $(30,60$ and $90 \mathrm{~cm})$. Onion cv. Giza 61 was used. The plants were irrigated by flood irrigation system. Irrigation water was added and quantities were adjusted to ensure a drainage rate of $15-25 \%$ and the total amount of water was calculated by Penman-Monteith equation. In the experiment, every lysimeter contained two rows contained forty plants.

\section{The studied characters}

At the end of the season, length, plant fresh weight, bulb diameter, neck diameter, bulbing ratio, total yield, dry matter and total soluble solids of bulb were recorded. Cupper was determined in the dry matter of bulb by spectrophotometer.

\section{Crop water use}

Actual crop evapotranspiration (ETc) was estimated by $E T c=K c^{*} E T O$. Thus, the crop coefficient (Kc) was estimated during the growing season period as follows: $\mathrm{Kc}=\mathrm{ETc} / \mathrm{ETo}$. The ETo is a representation of the Ea request of climate, independent of crop development and management factors (Allen et al 1998). Weather data were obtained from Arid Land Institute Weather Station at Shubra El Kheima. ETo was calculated by Penman-Montieth equation as follows:

$E T_{o}=\frac{\frac{\Delta}{\lambda}\left(R_{n}-G\right)+\frac{2.146 \gamma}{(T+273)} \frac{\left(e^{*}-e\right)}{\left(r_{a} / 24 \times 60 \times 60\right)}}{\Delta+\gamma\left(1+r_{s} / r_{a}\right)}$

Where ETo = reference evapotranspiration $(\mathrm{mm} /$ day), $\mathrm{Rn}=$ net radiation at the crop surface $\left(\mathrm{MJm}^{-2}\right.$ /day), $\mathrm{G}=$ soil heat flux density $\left(\mathrm{MJm}^{-2} \mathrm{day}^{-1}\right), \mathrm{T}=$ mean daily air temperature at $2 \mathrm{~m}$ height $\left({ }^{\circ} \mathrm{C}\right), \mathrm{u} 2=$ wind speed at $2 \mathrm{~m}$ height (ma-1), $\mathrm{e}^{*}$ and e: saturation and actual vapor pressure $[\mathrm{kPa}], \Delta=$ slope vapour pressure curve $\left(\mathrm{KPa}^{\circ} \mathrm{C}^{-1}\right)$, rs: the standard hypothetical vegetated surface $=70[\mathrm{~s} / \mathrm{m}]$ and ra: the aerodynamic resistance $[\mathrm{s} / \mathrm{m}]$. and $\mathrm{Y}=$ psychrometic constant $\left(\mathrm{KPa}^{\circ} \mathrm{C}^{-1}\right)$.

Water use efficiency was defined as ratio of yield to irrigation water requirement (De Pascale et al 2005) and it was calculated for different treatments by the following equation (Vites, 1965).

W.U.E=Yield/irrigation water requirement $(\mathrm{kg}$ $\mathrm{crop} / \mathrm{m}^{3}$ irrigation water). 
Table 1. Chemical properties of the $0-30 \mathrm{~cm}$ soil layer in the experimental soils

\begin{tabular}{|c|c|c|c|c|c|c|c|c|c|c|}
\hline \multirow[b]{2}{*}{ Types of soil } & \multicolumn{4}{|c|}{ Cations ( $\mathrm{meq} / \mathrm{l}$ ) } & \multicolumn{4}{|c|}{ Anions (meq/l) } & \multirow{2}{*}{$\begin{array}{c}\text { Ec at } 25^{\circ} \mathrm{C} \\
\mathrm{dS} / \mathrm{m}\end{array}$} & \multirow{2}{*}{$\underset{1: 2.5}{\mathrm{pH}}$} \\
\hline & $\mathrm{K}^{+}$ & $\mathrm{Na}^{+}$ & $\mathbf{M g}^{++}$ & $\mathrm{Ca}^{++}$ & $\mathrm{So}_{4}=$ & $\mathrm{Cl}^{-}$ & $\mathrm{HCO}_{3}{ }^{-}$ & $\mathrm{CO}_{3}^{--}$ & & \\
\hline Sand & 0.31 & 16.09 & 3.5 & 7.1 & 5.11 & 21.56 & 0.33 & 0 & 2.7 & 7.8 \\
\hline Sandy clay & 1.21 & 34.69 & 9.0 & 9.1 & 8.70 & 44.59 & 0.71 & 0 & 5.47 & 7.99 \\
\hline Clay & 0.51 & 19.99 & 3.0 & 7.5 & 6.11 & 24.38 & 0.51 & 0 & 3.15 & 7.95 \\
\hline
\end{tabular}

\section{Statistical analysis}

The obtained data were statistically analyzed by the method described by Gomez and Gomez (1984). The statistical analysis was carried out using the CoStat package program (Version 6.303; CoHort Software, USA). Data were subjected to analysis of variance (ANOVA). The differences among means of data were compared by Duncan's Multiple Range Test (Waller and Duncan, 1969). All statistical determinations were made at $\mathrm{P} \leq$ 0.05 .

\section{RESULTS AND DISCUSSION}

\section{Growth parameters}

Data presented in Table (2) indicated that the irrigation levels had significant effect on plant length in clay and sandy clay soils in both seasons, while the irrigation levels had no significant effect in sandy soil in both seasons. The treatments of 125 and $100 \%$ ETc showed the best significant effects of plant length in clay soil in the first season and second season, respectively. Also, the treatments of $125 \%$ ETc gave the highest significant values of plant length in sandy clay soil in both seasons. Concerning the neck diameter, the irrigation levels did not significantly affect this character in both seasons, under all tested soils, except in the second season75\% ETc showed the lowest significant values of neck diameter, under sandy clay soil. The variations of the plant length values between the two seasons might be due to the differences in climatic conditions.

The results of plant length agree with those of Kumar et al (2007) who found that the parameter was increased by the increase of irrigation level and the treatments 100 and $120 \%$ ETc showed the highest significant values. Also, the results agree with those of Channagoudra et al (2009). Zheng et al (2013) reported that plant heights for treatments $40 \%, 60 \%$ and $80 \%$ ETc were significantly smaller than that of the non-stressed $100 \%$ ETC because of water stress impacts during the crop seasons. The highly stressed treatment (40\% ETc) had the most minimal plant height.

The irrigation levels had significant effect on bulb diameter in clay and sandy clay soils, but no significant effect was observed in sandy soil in both seasons Table (3). The treatments of 100 and $125 \%$ ETc showed the best significant values of bulb diameter in both seasons, except in the second season there was no significant difference in sandy clay soil. Regarding bulbing ratio, the irrigation levels did not have significant effectiveness in clay and sandy soils in both seasons, while the treatments of $75 \%$ ETc showed the highest significant values of bulbing ratio in sandy clay soil in the second season.

The difference in bulbing ratio might be due to difference in bulb and neck diameters. These results agree with those of Martin de Santa Olalla et al (2004), Kumar et al (2007) and Enciso et al (2009). Kumar et al (2007) showed that the level of $B$ grade (most favored size) bulbs was high (above half) in 100 and $120 \%$ ETc. The least level of $B$ and the most elevated level of $D$ (littlest measured bulbs) grade were created in the most prohibitive treatment $(60 \%$ ETc). Also, Kruse et al (1987), Shock et al $(1998,2000)$ and Enciso et al (2009) observed that huge onion sizes can be can be created when more water was utilized, and the water pressure influenced the size of the onion. Martin de Santa Olalla et al (1994) observed that bulb diameter is immediately related to amount of water used. 
Table 2. Effect of irrigation levels on plant length and neck diameter of onion in all soil types in 2014/2015 and $2015 / 2016$ seasons

\begin{tabular}{|c|c|c|c|c|c|c|c|c|c|c|c|c|}
\hline \multirow{3}{*}{ Treatments } & \multicolumn{4}{|c|}{ Clay soil } & \multicolumn{4}{|c|}{ Sandy soil } & \multicolumn{4}{|c|}{ Sandy clay soil } \\
\hline & \multicolumn{2}{|c|}{$\begin{array}{l}\text { Plant length } \\
\text { (cm) }\end{array}$} & \multicolumn{2}{|c|}{$\begin{array}{c}\text { Neck diameter } \\
(\mathrm{mm})\end{array}$} & \multicolumn{2}{|c|}{$\begin{array}{l}\text { Plant length } \\
\text { (cm) }\end{array}$} & \multicolumn{2}{|c|}{$\begin{array}{c}\text { Neck diameter } \\
(\mathrm{mm})\end{array}$} & \multicolumn{2}{|c|}{$\begin{array}{l}\text { Plant length } \\
\text { (cm) }\end{array}$} & \multicolumn{2}{|c|}{$\begin{array}{l}\text { Neck diameter } \\
(\mathrm{mm})\end{array}$} \\
\hline & $\begin{array}{c}1^{\text {st }} \\
\text { season }\end{array}$ & $\begin{array}{c}2^{\text {nd }} \\
\text { season }\end{array}$ & $\begin{array}{c}1^{\text {st }} \\
\text { season } \\
\end{array}$ & $\begin{array}{c}2^{\text {nd }} \\
\text { season }\end{array}$ & $\begin{array}{c}1^{\text {st }} \\
\text { season }\end{array}$ & $\begin{array}{c}2^{\text {nd }} \\
\text { season } \\
\end{array}$ & $\begin{array}{c}1^{\text {st }} \\
\text { season }\end{array}$ & \begin{tabular}{|c|}
$2^{\text {nd }}$ \\
season \\
\end{tabular} & $\begin{array}{c}1^{\text {st }} \\
\text { season } \\
\end{array}$ & \begin{tabular}{|c|}
$2^{\text {nd }}$ \\
season \\
\end{tabular} & $\begin{array}{c}1^{\text {st }} \\
\text { season } \\
\end{array}$ & $\begin{array}{c}2^{\text {nd }} \\
\text { season }\end{array}$ \\
\hline $75 \%$ ETc & $65.16 \mathrm{ab}$ & $.37 a b$ & $9.53 \mathrm{a}$ & $13.25 \mathrm{a}$ & $57.66 \mathrm{a}$ & $36.88 \mathrm{a}$ & $8.71 \mathrm{a}$ & $10.33 \mathrm{a}$ & $59.83 \mathrm{~b}$ & $20.49 b$ & $8.11 \mathrm{a}$ & $6.69 \mathrm{~b}$ \\
\hline $100 \%$ & $55.33 \mathrm{~b}$ & $64.05 \mathrm{a}$ & $9.03 \mathrm{a}$ & $13.50 \mathrm{a}$ & $58.33 \mathrm{a}$ & $44.99 \mathrm{a}$ & $8.15 \mathrm{a}$ & $10.66 \mathrm{a}$ & $59.33 \mathrm{~b}$ & $48.76 \mathrm{a}$ & $8.20 \mathrm{a}$ & 1 \\
\hline $125 \%$ ETc & $73 a$ & $45.15 \mathrm{~b}$ & $9.15 \mathrm{a}$ & $12.67 \mathrm{a}$ & $60.66 \mathrm{a}$ & $45.15 \mathrm{a}$ & $9.20 \mathrm{a}$ & $12.66 \mathrm{a}$ & $72.16 \mathrm{a}$ & $38.72 \mathrm{a}$ & $10.51 \mathrm{a}$ & $11.00 \mathrm{a}$ \\
\hline
\end{tabular}

ETc : Evapotranspiration crop.

Means followed by the same letter are not significantly different $(P \leq 0.05)$ according to Duncan's multiple range test.

Table 3. Effect of irrigation levels on bulb diameter and bulbing ratio of onion in all soil types in 2014/2015 and $2015 / 2016$ seasons

\begin{tabular}{|c|c|c|c|c|c|c|c|c|c|c|c|c|}
\hline \multirow{3}{*}{ Treatments } & \multicolumn{4}{|c|}{ Clay soil } & \multicolumn{4}{|c|}{ Sandy soil } & \multicolumn{4}{|c|}{ Sandy clay soil } \\
\hline & \multicolumn{2}{|c|}{$\begin{array}{l}\text { Bulb diameter } \\
(\mathbf{m m})\end{array}$} & \multicolumn{2}{|c|}{$\begin{array}{l}\text { Bulbing } \\
\text { ratio }\end{array}$} & \multicolumn{2}{|c|}{$\begin{array}{c}\text { Bulb diameter } \\
(\mathrm{mm})\end{array}$} & \multicolumn{2}{|c|}{$\begin{array}{l}\text { Bulbing } \\
\text { ratio }\end{array}$} & \multicolumn{2}{|c|}{$\begin{array}{c}\text { Bulb diameter } \\
(\mathrm{mm})\end{array}$} & \multicolumn{2}{|c|}{$\begin{array}{l}\text { Bulbing } \\
\text { ratio }\end{array}$} \\
\hline & $\begin{array}{c}1^{\text {st }} \\
\text { season } \\
\end{array}$ & \begin{tabular}{|c|}
$2^{\text {nd }}$ \\
season \\
\end{tabular} & $\begin{array}{c}1^{\text {st }} \\
\text { season } \\
\end{array}$ & \begin{tabular}{|c|}
$2^{\text {nd }}$ \\
season \\
\end{tabular} & $\begin{array}{c}1^{\text {st }} \\
\text { season }\end{array}$ & \begin{tabular}{|c|}
$2^{\text {nd }}$ \\
season
\end{tabular} & \begin{tabular}{|c|}
$1^{\text {st }}$ \\
season \\
\end{tabular} & \begin{tabular}{|c|}
$2^{\text {nd }}$ \\
season \\
\end{tabular} & $\begin{array}{c}1^{\text {st }} \\
\text { season } \\
\end{array}$ & $\begin{array}{c}2^{\text {nd }} \\
\text { season }\end{array}$ & $\begin{array}{c}1^{\text {st }} \\
\text { season } \\
\end{array}$ & \begin{tabular}{|c|}
$2^{\text {nd }}$ \\
season \\
\end{tabular} \\
\hline $75 \%$ ETc & $49.02 \mathrm{~b}$ & $57.06 \mathrm{~b}$ & $5.196 \mathrm{a}$ & $4.489 \mathrm{a}$ & $52.88 \mathrm{a}$ & $53.40 \mathrm{a}$ & $6.106 \mathrm{a}$ & $5.37 \mathrm{a}$ & $49.91 \mathrm{~b}$ & $61.06 \mathrm{a}$ & $6.15 \mathrm{a}$ & $9.22 \mathrm{a}$ \\
\hline $100 \%$ ETc & 54.89ab & $66.39 \mathrm{a}$ & $6.104 \mathrm{a}$ & $4.953 \mathrm{a}$ & $52.17 \mathrm{a}$ & $52.91 \mathrm{a}$ & $6.398 \mathrm{a}$ & $5.07 \mathrm{a}$ & $52.16 a b$ & $62.13 \mathrm{a}$ & $6.45 \mathrm{a}$ & $4.91 \mathrm{~b}$ \\
\hline $125 \%$ ETc & $59.07 \mathrm{a}$ & $61.36 a b$ & $6.543 \mathrm{a}$ & 4. $854 \mathrm{a}$ & $53.09 \mathrm{a}$ & $61.36 \mathrm{a}$ & $5.837 \mathrm{a}$ & $4.53 \mathrm{a}$ & $62.65 \mathrm{a}$ & $60.25 \mathrm{a}$ & $6.11 \mathrm{a}$ & $5.49 \mathrm{~b}$ \\
\hline
\end{tabular}

ETc : Evapotranspiration crop

Means followed by the same letter are not significantly different $(P \leq 0.05)$ according to Duncan's multiple range test.

\section{Bulb yield and quality}

Data in Table (4) indicate that the irrigation levels had significant effectiveness on total and marketable bulb yields in clay soil in the first season; the treatment of $125 \%$ ETc gave the best significant values, while the irrigation levels had no significant effect in the second season. Also, the irrigation levels did not have significant effect on total and marketable yield in sandy and sandy clay soils in both seasons.

The results agree with those of Chung (1989), who observed that water stress during necessary development time causes decrease in size and weight of bulbs. Shock et al $(1998,2000)$ and Kruse et al (1987) obtained greater total marketable yields with wetter treatments. These results are in accordance with those of Orta and Ener (2001) and Kumar et al (2007) in clay soil, where Kumar et al (2007) observed that the difference in onion yield between the treatments was registered because of the difference in bulb size and mean weight of bulbs. Also, Zheng et al (2013) demonstrated that onion bulb production is very delicate to water stress during the development and bulbification stages, but not touchy during the establishment and ripening stages. Results additionally show that the distinction in bulb yields basically came about because of the variety in bulb weight and bulb size (Prashar et al 1994; Orta and Fener 2001; Channagoudra et al 2009).

The obtained results of sandy and sandy clay soils agree with those of Enciso et al (2009) and Assefa et al (2016), who observed that, in both seasons, there were no differences in total yield between 100 and $75 \%$ ETc treatments because approximately like soil moisture conditions were observed. A drop in moisture was shown below these water levels. Some studies in Ethiopia and elsewhere in the world appeared non-significant 
Table 4. Effect of irrigation levels on total and marketable yields of onion in all soil types in 2014/2015 and $2015 / 2016$ seasons

\begin{tabular}{|c|c|c|c|c|c|c|c|c|c|c|c|c|}
\hline \multirow{3}{*}{ Treatments } & \multicolumn{4}{|c|}{ Clay soil } & \multicolumn{4}{|c|}{ Sand soil } & \multicolumn{4}{|c|}{ Sandy clay soil } \\
\hline & \multicolumn{2}{|c|}{$\begin{array}{c}\text { Marketable yield } \\
\left(\mathrm{Kg} / \mathrm{m}^{2}\right) \\
\end{array}$} & \multicolumn{2}{|c|}{$\begin{array}{l}\text { Total yield } \\
\left(\mathrm{Kg} / \mathrm{m}^{2}\right)\end{array}$} & \multicolumn{2}{|c|}{$\begin{array}{l}\text { Marketable yield } \\
\qquad\left(\mathrm{Kg} / \mathrm{m}^{2}\right)\end{array}$} & \multicolumn{2}{|c|}{$\begin{array}{l}\text { Total yield } \\
\left(\mathrm{Kg} / \mathrm{m}^{2}\right)\end{array}$} & \multicolumn{2}{|c|}{$\begin{array}{c}\text { Marketable yield } \\
\left(\mathrm{Kg} / \mathrm{m}^{2}\right)\end{array}$} & \multicolumn{2}{|c|}{$\begin{array}{l}\text { Total yield } \\
\left(\mathrm{Kg} / \mathrm{m}^{2}\right)\end{array}$} \\
\hline & \begin{tabular}{|c|}
$1^{\text {st }}$ \\
season \\
\end{tabular} & $\begin{array}{c}2^{\text {nd }} \\
\text { season } \\
\end{array}$ & $\begin{array}{c}1^{\text {st }} \\
\text { season } \\
\end{array}$ & \begin{tabular}{|c|}
$2^{\text {nd }}$ \\
season \\
\end{tabular} & \begin{tabular}{|c|}
$1^{\text {st }}$ \\
season \\
\end{tabular} & $\begin{array}{c}2^{\text {nd }} \\
\text { season } \\
\end{array}$ & $\begin{array}{c}1^{\text {st }} \\
\text { season } \\
\end{array}$ & \begin{tabular}{|c|}
$2^{\text {nd }}$ \\
season \\
\end{tabular} & \begin{tabular}{|c|}
$1^{\text {st }}$ \\
season \\
\end{tabular} & \begin{tabular}{|c|}
$2^{\text {nd }}$ \\
season \\
\end{tabular} & $\begin{array}{c}1^{\text {st }} \\
\text { season }\end{array}$ & \begin{tabular}{|c|}
$2^{\text {nd }}$ \\
season \\
\end{tabular} \\
\hline $75 \%$ ETc & $1.616 \mathrm{~b}$ & $0.818 a$ & $2.38 \mathrm{~b}$ & $1.598 \mathrm{a}$ & $0.956 \mathrm{a}$ & $0.165 a$ & $1.570 \mathrm{a}$ & $0.646 \mathrm{a}$ & $1.257 \mathrm{a}$ & $0.340 \mathrm{a}$ & $1.87 \mathrm{a}$ & $1.06 \mathrm{a}$ \\
\hline $100 \%$ ETc & $0.963 \mathrm{c}$ & $1.163 a$ & $1.63 \mathrm{c}$ & $2.061 \mathrm{a}$ & $0.668 \mathrm{a}$ & $0.383 a$ & $1.290 \mathrm{a}$ & $0.975 \mathrm{a}$ & $0.938 \mathrm{a}$ & $0.623 \mathrm{a}$ & $1.67 \mathrm{a}$ & $1.49 \mathrm{a}$ \\
\hline $125 \%$ ETc & $2.306 \mathrm{a}$ & $0.828 \mathrm{a}$ & $3.03 \mathrm{a}$ & $1.553 \mathrm{a}$ & $1.298 \mathrm{a}$ & $0.428 \mathrm{a}$ & $1.950 \mathrm{a}$ & $1.22 \mathrm{a}$ & $1.581 \mathrm{a}$ & $0.381 \mathrm{a}$ & $2.34 \mathrm{a}$ & $1.14 \mathrm{a}$ \\
\hline
\end{tabular}

ETc : Evapotranspiration crop.

Means followed by the same letter are not significantly different $(P \leq 0.05)$ according to Duncan' s multiple range test.

differences in fresh onion bulb yield between 75 and $100 \%$ ETc irrigation levels (Bekele and Tilahun, 2007; Nagaz et al 2012). Similar to this study, Enciso et al (2009) indicated that harvestable onion yield and water productivity lowered significantly when irrigation levels decreased from 75 to $50 \%$ ETc.

Concerning total soluble solids, data in Table (5) show that the irrigation levels had no significant effects on total soluble solids in both seasons, except in the second season the application of $125 \%$ ETc showed the lowest significant values of TSS in sandy and sandy clay soils.
The results of TSS agree with those of Zheng et al (2013), Orta and Fener (2001) and Enciso et al (2009), who demonstrated that TSS of onion bulbs were not influenced by the water system level. TSS content showed to be low responsive to variations in irrigation management. Also, Kumar et al (2007), Abd El-Al et al (2010) and Leskovar et al (2012). Kumar et al (2007) observed that that TSS of onion bulb have been expanded with the expansion in water system from 60 to $100 \%$ ETc in first season, while in second season water system had no huge impact on TSS. Though, results are in accordance with Chopade et al (1998) who decided higher TSS in onion with ideal utilization of water.

Table 5. Effect of irrigation levels on total soluble solids percent onion in all soil types in 2014/2015 and $2015 / 2016$ seasons

\begin{tabular}{|l|c|c|c|c|c|c|}
\hline \multirow{2}{*}{ Treatments } & \multicolumn{2}{|c|}{ Clay soil } & \multicolumn{2}{c|}{ Sand soil } & \multicolumn{2}{c|}{ Sandy clay soil } \\
\cline { 2 - 7 } & $\mathbf{1}^{\text {st }}$ season & $\mathbf{2}^{\text {nd }}$ season & $\mathbf{1}^{\text {st }}$ season & $\mathbf{2}^{\text {nd }}$ season & $\mathbf{1}^{\text {st }}$ season & $2^{\text {nd }}$ season \\
\hline $75 \%$ ETc & $16.16 \mathrm{a}$ & $12.00 \mathrm{a}$ & $16.73 \mathrm{a}$ & $12.66 \mathrm{a}$ & $15.1 \mathrm{a}$ & $12.26 \mathrm{a}$ \\
$100 \%$ ETc & $15.56 \mathrm{a}$ & $11.73 \mathrm{a}$ & $16.76 \mathrm{a}$ & $12.4 \mathrm{a}$ & $16.2 \mathrm{a}$ & $12.33 \mathrm{a}$ \\
$125 \%$ ETc & $16.16 \mathrm{a}$ & $11.23 \mathrm{a}$ & $16.16 \mathrm{a}$ & $11.2 \mathrm{~b}$ & $15.0 \mathrm{a}$ & $11.06 \mathrm{~b}$ \\
\hline
\end{tabular}

ETc : Evapotranspiration crop.

Means followed by the same letter are not significantly different $(P \leq 0.05)$ according to Duncan's multiple range test.

Data in Table (6) indicate that the irrigation levels had significant effects on dry matter of bulb in clay soil in both seasons, where the application of $75 \%$ ETc showed the highest significant values of dry matter of bulb in both seasons. Also, the irrigation levels had significant effectiveness on dry matter of bulb in sandy soil in the second season and in sandy clay soil in the first season, where the application of 125 and $75 \%$ ETc gave the best significant values of dry matter of bulb in sandy and sandy clay soils in the second and the first seasons, respectively. With respect to the concentration of $\mathrm{Cu}$ in bulb, the irrigation levels had no significant effects in both seasons, except in the second and the first seasons, the treatments of 75 and $100 \%$ ETc showed the lowest significant values in clay and sandy clay soils, respectively. 
Table 6. Effect of irrigation levels on dry matter of bulb and content of $\mathrm{Cu}$ in bulb of onion in all soil types in 2014/2015 and 2015/2016 seasons

\begin{tabular}{|c|c|c|c|c|c|c|c|c|c|c|c|c|}
\hline \multirow{3}{*}{ Treatments } & \multicolumn{4}{|c|}{ Clay soil } & \multicolumn{4}{|c|}{ Sand soil } & \multicolumn{4}{|c|}{ Sandy clay soil } \\
\hline & \multicolumn{2}{|c|}{$\begin{array}{l}\text { Dry matter of } \\
\text { bulb(g) }\end{array}$} & \multicolumn{2}{|c|}{$\begin{array}{l}\text { Content of } \mathrm{Cu} \\
\text { in bulb(ppm) }\end{array}$} & \multicolumn{2}{|c|}{$\begin{array}{l}\text { Dry matter of } \\
\text { bulb }(g)\end{array}$} & \multicolumn{2}{|c|}{$\begin{array}{l}\text { Content of Cu } \\
\text { in bulb(ppm) }\end{array}$} & \multicolumn{2}{|c|}{$\begin{array}{l}\text { Dry matter of } \\
\text { bulb }(g)\end{array}$} & \multicolumn{2}{|c|}{$\begin{array}{l}\text { Content of } \mathrm{Cu} \\
\text { in bulb(ppm) }\end{array}$} \\
\hline & $\begin{array}{c}1^{\text {st }} \\
\text { season }\end{array}$ & $\begin{array}{c}2^{\text {nd }} \\
\text { season } \\
\end{array}$ & $\begin{array}{c}1^{\text {st }} \\
\text { season } \\
\end{array}$ & $\begin{array}{c}2^{\text {nd }} \\
\text { season } \\
\end{array}$ & $\begin{array}{c}1^{\text {st }} \\
\text { season } \\
\end{array}$ & $\begin{array}{c}2^{\text {nd }} \\
\text { season }\end{array}$ & $\begin{array}{c}1^{\text {st }} \\
\text { season }\end{array}$ & \begin{tabular}{|c|}
$2^{\text {nd }}$ \\
season
\end{tabular} & $\begin{array}{c}1^{\text {st }} \\
\text { season } \\
\end{array}$ & \begin{tabular}{|c|}
$2^{\text {nd }}$ \\
season \\
\end{tabular} & \begin{tabular}{|c|}
$1^{\text {st }}$ \\
season \\
\end{tabular} & $\begin{array}{c}2^{\text {nd }} \\
\text { season } \\
\end{array}$ \\
\hline $75 \%$ & $24.44 \mathrm{a}$ & $20.08 \mathrm{ab}$ & $16.61 \mathrm{a}$ & $16.52 \mathrm{~b}$ & $21.60 \mathrm{a}$ & $23.18 b$ & $16.68 \mathrm{a}$ & $16.53 a$ & $22.25 a$ & $21.18 \mathrm{a}$ & $16.63 a$ & $10.0<\mathrm{a}$ \\
\hline $100 \%$ ETc & $18.25 \mathrm{~b}$ & $18.71 \mathrm{~b}$ & $16.48 \mathrm{a}$ & $16.69 \mathrm{a}$ & $21.11 \mathrm{a}$ & $22.19 b$ & $16.58 \mathrm{a}$ & $16.65 \mathrm{a}$ & $18.57 \mathrm{~b}$ & $21.77 \mathrm{a}$ & $16.48 \mathrm{~b}$ & $16.5 \mathrm{a}$ \\
\hline $125 \%$ ETc & 19.32ab & $20.85 \mathrm{a}$ & $17.00 \mathrm{a}$ & $16.72 \mathrm{a}$ & $20.75 a$ & $31.13 \mathrm{a}$ & $16.68 \mathrm{a}$ & $16.49 \mathrm{a}$ & $18.31 \mathrm{~b}$ & $21.05 \mathrm{a}$ & $16.55 \mathrm{ab}$ & 16.56 \\
\hline
\end{tabular}

ETc : Evapotranspiration crop.

Means followed by the same letter are not significantly different $(P \leq 0.05)$ according to Duncan' s multiple range test.

Kumar et al (2007) demonstrated that the variation in bulb dry weight per plant may be ascribed to distinction in size of bulb. Also, Zheng et al (2013) observed that the mean bulb weight and the bulb sizes were influenced by the level and timing of water stress in a similar way the bulb dry weight per plant since these quality parameters are highly related to the bulbification elements.

\section{Crop water use}

Water use efficiency for different of irrigation levels was determined in both seasons, where the application of $100 \%$ ETc showed the best values in both seasons (Table 7). These results agree with those of Kumar et al (2007) who observed that the expansion in yield was practically straight with ETc up to treatment $100 \%$ ETc.
Table 7. Effect of irrigation levels on WUE for onion in $2014 / 2015$ and $2015 / 2016$ seasons

\begin{tabular}{|c|c|c|}
\hline Treatments & $\mathbf{1}^{\text {st }}$ season & $\mathbf{2}^{\text {nd }}$ season \\
\hline $75 \%$ ETc & 2.98 & 2.88 \\
$100 \%$ ETc & 8.68 & 5.35 \\
$125 \%$ ETc & 7.56 & 2.60 \\
\hline
\end{tabular}

Data in Table (8) offer the values of crop coefficient $(\mathrm{Kc})$ for the different irrigation levels for growth stages of onion in both seasons, where the value of crop coefficient for the treatment of $100 \%$ ETc was the FAO crop coefficient. These results observed the differences of crop coefficient values at the same treatment in both seasons which might be due to the variation in climatic conditions.

Table 8. Effect of irrigation levels and soil types on crop coefficient (Kc) for onion in 2014/2015 and 2015/2016 seasons

\begin{tabular}{|l|c|c|c|c|c|c|}
\hline \multirow{2}{*}{ Growth stage } & \multicolumn{3}{|c|}{$\mathbf{1}^{\text {st }}$ season } & \multicolumn{3}{c|}{ 2 $^{\text {nd }}$ season } \\
\cline { 2 - 7 } & $\begin{array}{c}\text { Kc } \\
\text { at75\%ETc }\end{array}$ & $\begin{array}{c}\text { Kc } \\
\text { at100\%ETc }\end{array}$ & $\begin{array}{c}\text { Kc } \\
\text { at125\%ETc }\end{array}$ & $\begin{array}{c}\text { Kc } \\
\text { at75\%ETc }\end{array}$ & $\begin{array}{c}\text { Kc } \\
\text { at100\%ETc }\end{array}$ & $\begin{array}{c}\text { Kc } \\
\text { at125\%ETc }\end{array}$ \\
\hline Initial & 0.38 & 0.40 & 0.63 & 0.36 & 0.48 & 0.60 \\
Crop development & 0.39 & 0.41 & 0.65 & 0.38 & 0.51 & 0.64 \\
Mid-season & 1.04 & 1.10 & 1.73 & 0.93 & 1.25 & 1.56 \\
Late season & 0.80 & 0.87 & 0.95 & 0.68 & 0.90 & 0.93 \\
\hline
\end{tabular}

Data in Fig. (1) show the values of reference crop coefficient (Kc100) and the average of crop coefficient values for the different irrigation levels for growth stages of onion in both seasons under Delta Nile conditions, where there were differences among these values of $\mathrm{Kc}$. The differences of these values of $\mathrm{Kc}$ may be due to the variation of conditions. The average of $\mathrm{Kc}$ values during initial, crop development, mid-season and late season stages were $0.47,0.5,1.24$ and 0.99 , respectively, while the reference $\mathrm{Kc}$ values during establishment, crop development, mid-season and late season stages were $0.4,0.41,1.1$ and 0.87 , respectively. 


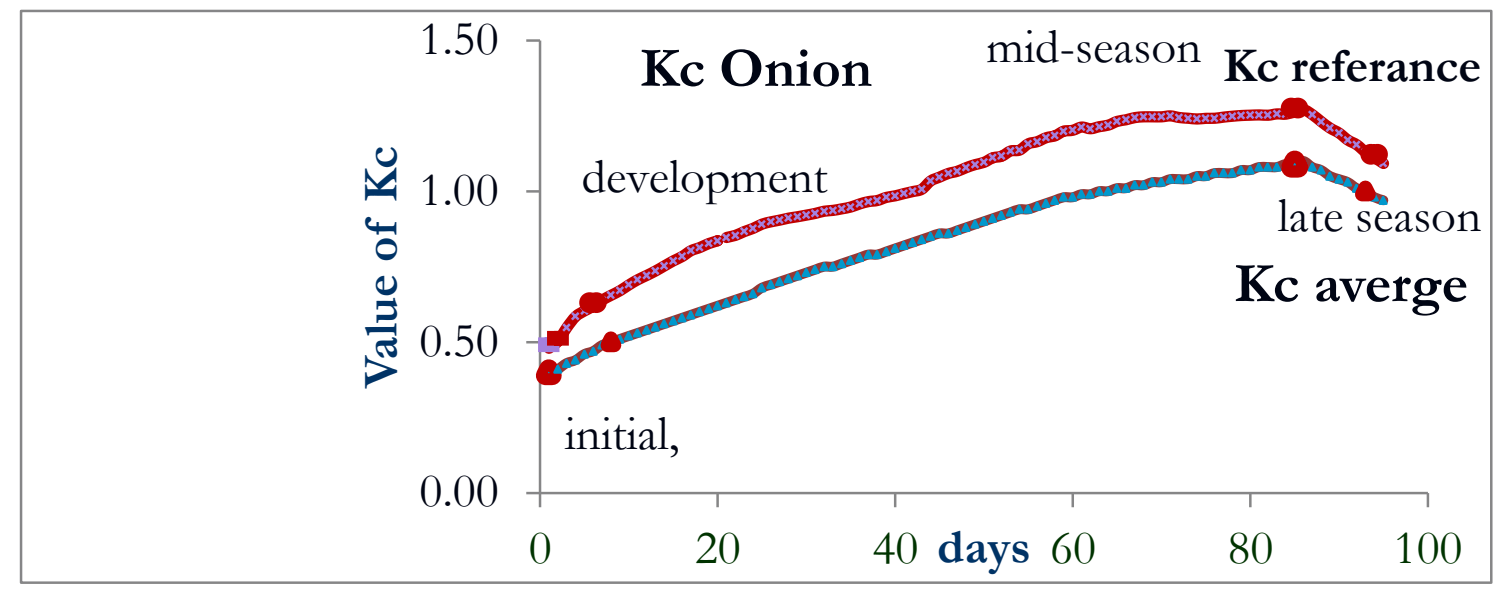

Fig. 1. Effect of irrigation levels and soil types on crop coefficient reference and average of crop coefficient for onion in $2015 / 2016$ seasons

Dirirsa et al (2015) found that the calculated overall average Kc values during initial, crop development, mid-season and late season stages were $0.61,0.86,1.02$ and 0.80 , respectively, while the $\mathrm{Kc}$ values which were suggested by Allen et al (1998) for dry onion were $0.7,1.05$, and 0.75 for the initial stage, midseason stage, and end of lateseason, respectively. Also, Bossie et al (2009) observed that the determined values of Kc for dry bulb onion (Bombay Red cultivar) during initial, mid-season, and end season stages were0.47, 0.99 , and 0.46 , respectively.

\section{CONCLUSION}

In this study, the crop evapotranspiration (ETc), water use efficiency and crop coefficient were estimated for onion under Delta Nile conditions. it could be concluded that the increase of irrigation water levels (100 and $125 \%$ ETc) were the best treatments for some growth parameters such as plant length and bulb diameter in clay and sandy clay soils, as well as bulb $\mathrm{Cu}$ concentrations total and marketable bulb yield in clay soil, but the treatment of $75 \%$ was the best treatment for dry matter of bulb, TSS\% and bulbing ratio in sandy clay soil. Concerning the sandy soil, irrigation levels nearly had slightly effects on all growth parameters. The averages of crop coefficient values were $0.47,0.5,1.24$ and 0.99 during initial, development, mid-season and end-season growth stages, respectively. Water use efficiency for onion was estimated for all treatments and the most effective treatment was $100 \%$.
Thus, the actual of evapotranspiration for onion in Egypt can be determined after estimating of reference evapotranspiration by Penman-Monteith method from the nearest meteorological station.

\section{REFERENCES}

Abd El-Al F.S., Shaheen A.M., Rizk F.A. and Hafez M.M. 2010. Influence of irrigation intervals and potassium fertilization on productivity and quality of onion plant. Int. J. Acad. Res. 2(1), 110-116.

Allen R.G., Pereira L.S., Raes D. and Smith M. 1998. Crop evapotranspiration guidelines for computing crop water requirements. FAO Irrigation and Drainage Paper No. 56. Rome, Italy, $290 \mathrm{p}$.

Assefa S., Biazin B., Muluneh A., Yimer F. and Haileslassie A. 2016. Rainwater harvesting for supplemental irrigation of onions in the southern dry lands of Ethiopia. Agricultural Water Management 178, 325-334.

Bekele S. and Tilahun K. 2007. Regulated deficit irrigation scheduling of onion in a semiarid region of Ethiopia. Agric. Water Management. 89(1-2), 148-152.

Bossie M., Tilahun K. and Hordofa T. 2009. Crop coefficient and evapotranspiration of onion at Awash Melkassa, Central Rift Valley of Ethiopia. Irrig. Drainage Syst. 23, 1-10.

Brewster J.L. 2008. Onions and other vegetable alliums $2^{\text {nd }}$ ed., UK: Biddles Ltd, King's Lynn. $448 \mathrm{p}$. 
Channagoudra R.F., Prabhudeva A. and Kamble A.S. 2009. Response of onion (Allium cepa L.) to different levels of irrigation and sulphur in alfisols of northern transitional tract of Karnataka. Asian J. Hortic. 4(1), 152-155.

Chopade S.O., Bansode P.N. and Hiwase S.S. 1998. Studies on fertilizer and water management to onion. PKV Res. J. 22, 44-47.

Chung B. 1989. Irrigation and bulb onion quality. Acta Hort. 247, 233-236.

De Pascale S., Maggio A. and Barbieri G. 2005. Soil salinization affects growth, yield and mineral composition of cauliflower and broccoli. Eur. J. Agron. 23, 254-264

Dirirsa G., Hordofa T. and Bekele D. 2015. Water Requirement and Crop Coefficient of Onion (Red Bombay) in the Central Rift Valley of Ethiopia. Int. J. of Recent Research in Life Sci., 2(1), 1-6.

Enciso J., Wiedenfeld B., Jifon J. and Nelson S. 2009. Onion yield and quality response to two irrigation scheduling strategies. Sci. Hortic. 120, 301-305.

FAOSTAT 2017. Food and Agriculture organizations of the United Nations. Statistics Division. http://www.fao.org/faostat/en/\#data/QC (accessed 4, May 2019).

Gomez K.A. and Gomez A.A. 1984. Statistical procedures for agricultural research $2^{\text {nd }}$ ed. John wiley and sons, New York, USA, 680 p.

Kang S., Gu B., Du T. and Zhang J. 2003. Crop coefficient and ratio of transpiration to evapotranspiration of winter wheat and maize in a semi humid region. Agric. Water Management 59(1), 239-254.

Kruse E.G., Ells J.E. and McSay A.E. 1987. Comparison of two onion irrigation scheduling programs. J. Am. Soc. Hortic. Sci., 112, 738742.

Kumar S., Imtiyaz M., Kumar A. and Singh R. 2007. Response of onion (Allium cepa L.) to different levels of irrigation water. Agric. Water Management. 89, 161-166.

Leskovar D.I., Agehara S., Yoo K. and PascualSeva N. 2012. Crop coefficient-based deficit irrigation and planting density for onion: growth, yield, and bulb quality. Hort. Sci. 47(1), 31-37.
Martin de Santa Olalla F., Valero J.A.J. and Cortes C.F. 1994. Growth and production of onion crop (Allium cepa L.) under different irrigation scheduling. Eur. J. Agron. 3(1), 85-92.

Mariın de Santa Olalla F.J., Dominguez-Padilla A. and Lo'pez R. 2004. Production and quality of onion crop (Allium cepa L.) cultivated under controlled deficit irrigation conditions in a semiarid climate. Agric. Water Manag 68, 77-89.

Nagaz K., Masmoudi M.M. and Mechlia B.N. 2012. Yield response of drip-Irrigated onion under full and deficit irrigation with Saline water in arid regions of Tunisia. Int. Scholarly Res. Network ISRN Agronomy. 2012, 8 p.

Orta A.H. and Ener M. 2001. Irrigation scheduling of onion (Allium cepa L.) in Turkey. J. Biol. Sci. 1(8), 735-736.

Prashar C.R.K., Sharma G.C. and Gandah M. 1994. Evapotranspiration of onion in Sahelian Niger. Exp. Agric. 30, 473-476.

Shock C.C., Feibert E.B.G. and Saunders L.D. 1998. Onion yield and quality affected by soil water potential as irrigation threshold. Hortscience 33 (7), 1188-1191.

Shock C.C., Feibert E.B.G. and Saunders L.D. 2000. Irrigation criteria for drip irrigated onions. Hortscience 35(1), 63-66.

Surendran U., Sushanth C.M., Mammen G. and Joseph E.J. 2015. Modelling the crop water requirement using $\mathrm{FAO}-\mathrm{CROPWAT}$ and assessment of water resources for sustainable water resource management: A case study in Palakkad district of humid tropical Kerala, India. Aquatic Procedia. 4, 1211-1219.

Vites F.G.Jr. 1965. Increasing water efficiency by soil management. Amer. Soci. Agron., Wisc. 26, 259-274.

Waller R.A. and Duncan D.B. 1969 .A Bayes rule for the symmetric multiple comparisons problem. J. of the American Statistical Association. 64, 1484-1503.

Zheng J., Huang G., Wang J., Huang Q., Pereira L.S., Xu X. and Liu H. 2013. Effects ofwater deficits on growth, yield and water productivity of drip-irrigated onion (Allium cepa L.) in an arid region of Northwest China. Irrig. Sci. 31, 9951008. 


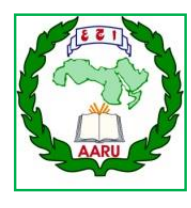

مجلة اتحاد الجامعاث العربية للعلوم الزراعية، جامعة عين شمس، القاهرة، مصر مجلا(27)، عدد(5)، 2661-2653، 2019

Website: http://ajs.journals.ekb.eg

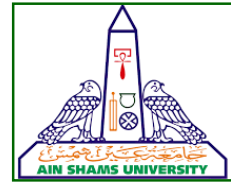

2661

تقدير معامل نمو المحصول لمحصول البصل تحت ظروف دلتا النيل

[212]

$$
\begin{aligned}
& \text { هند محمد نصار" - محمد زكي الثناوي - اسامه أحمد البحيري - ايمن فريد ابوحديد } \\
& \text { قسم البساتين - كلية الزراعة - جامعة عين شمس - ص.ب. } 68 \text { - حدائق شبرا } 11241 \text { - القاهرة - مصر }
\end{aligned}
$$

*Corresponding author: hend667@agr.asu.edu.eg

Accepted 2 December, 2019

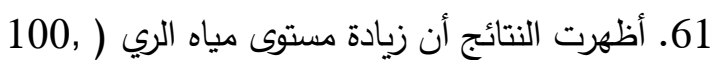

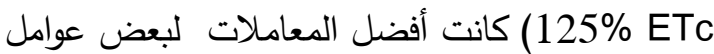
النمو مثل طول النبات وقطر البصلة والمحصول والأبصال الصالحة للتسويق وتركيز النحاس في فلئ 75\%ETc الأبصال فى التربة الطينية، ولكن معاملة كانت الأفضل للمادة الجافة والمواد الصلبة الذائبة الكلية ونسبة التبصيل في التربة الطميية. وكان قيم

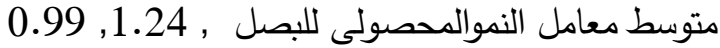
0.47, 0.5 خلال مرحلة النمو الأولية ، ومرحلة التطور ومنتصف الموسم ونهاية الموسم على التولى التوالي. قدرت كفاءة استخدام الماء للمعاملات وكانت معاملة 100\% هي الأفضل.

الكلمات الدالة: البصل، الاحتياجات المائية، البخرنتح،

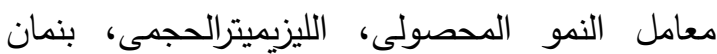
مونتيث
تعد مصر منطقة شبه قاحلة، ولذا تعتمد الزراعة

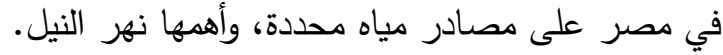

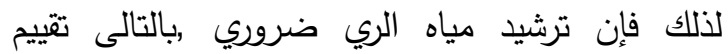

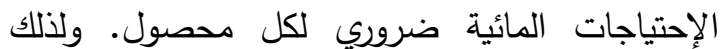

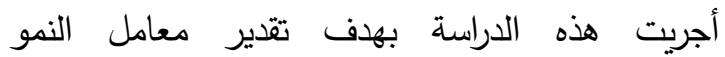
المحصول (Kc) لمراحل النمو المختلفة لنبات البصل و تقدير الاحتياجات المائية وكفاءة استخدام المياه.

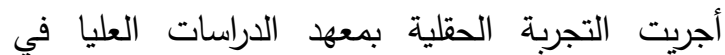
الأراضي القاحلة، جامعة عين شمس، شبرات الجرات الخيمة،

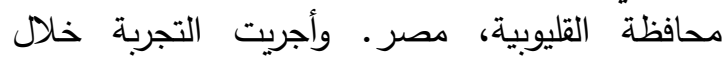
موسمى 2014/2015 و2015/2016 تحت ظروف

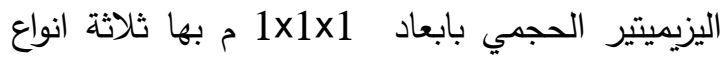
تربة مختلفة (طينية، رملية، طينية رملية) واشتملت

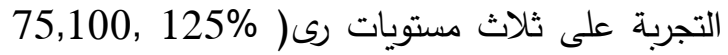

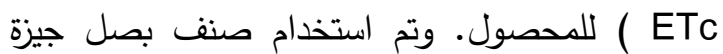

